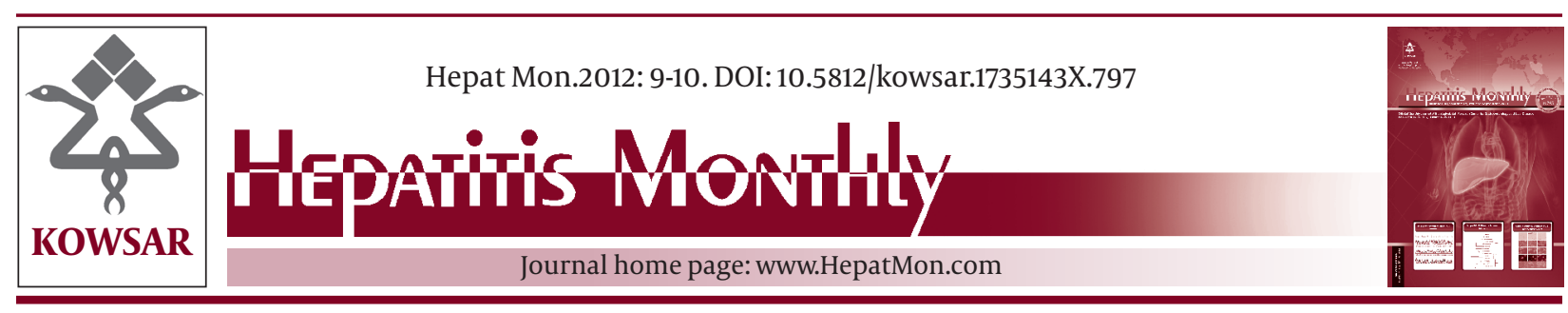

\title{
Intravenous Drug Use and Hepatitis C Virus in Iran
}

\author{
Mehdi Zobeiri ${ }^{{ }^{*}}$, Peyman Adibi $^{2}$, Seyed Moayed Alavian ${ }^{3}$ \\ ${ }^{1}$ Department of Internal Medicine, Kermanshah University of Medical Sciences, School of Medicine, Imam Reza Hospital, Kermanshah, IR Iran \\ 2 Department of Gastroenterology, Isfahan University of Medical Sciences, Isfahan, IR Iran \\ ${ }^{3}$ Baqiyatallah Research Center for Gastroenterology and Liver Diseases, Baqiyatallah University of Medical Sciences, Tehran, IR Iran
}

\section{A R T I C L E I N F O}

\section{Article type:}

Editorial

Article history:

Received: 08 Dec 2011

Revised: 27 Dec 2011

Accepted: 07 Jan 2012

\section{Keywords:}

Substance Abuse

Intravenous

Hepatitis C

HCV infection is a global public health problem and can progress to cirrhosis, hepatic decompensation, hepatocellular carcinoma, and death, with asymptomatic conditions and few short-term effects in the beginning $(1,2)$. It is expected that over the next decade, despite a declining incidence of new infections, mortality and associated costs will increase (1). Worldwide prevalence rates range from 0.01 to $20 \%$, and the World Health Organization (WHO) estimates that up to $3 \%$ of the world's population (170 million) have been infected with HCV(3). Worldwide hepatitis $\mathrm{C}$ data show significant prevalence rates in high-risk populations, ranging from 30\% to 50\%, with injecting drug use being the predominant risk factor $(4,5)$. In most cases, HCV is spread parenterally, and research has identified intravenous and intranasal drug use, exposure to infected blood and blood products, and high-risk behaviors as risk factors in parenteral transmission (1). The variation in HCV prevalence creates the need for different preventive methods, community interventions, and therapeutic strategies based on economic and social variance (6). Drug addicts are a high-risk group for

${ }^{*}$ Corresponding author: Mehdi Zobeiri, Department of Internal Medicine, School of Medicine, Imam Reza Hospital, Kermanshah University of Medical Sciences, Kermanshah, IR Iran. Tel:+98-8314276309, Fax:+98-8314276298, E-mail:mzoberi@KUMS.ac.ir; mehdizobeiri@yahoo.com

DOI:10.5812/kowsar.1735143X.797

Copyright $\odot 2012$ Kowsar M.P.Co. All rights reserved.
Implication for health policy/practice/research/medical education:

This article focuses on HCV infection among intravenous drug users. Considering high prevalence of HCV among intravenous drug users and its effect in public health. This study is recommended to epidemiologists, hematologist, and infectious diseases specialists.

- Please cite this paper as:

Zobeiri M, Adibi P, Alavian SM. Intravenous Drug Use and Hepatitis C Virus in Iran. Hepat Mon. 2012;9-10. DOI: 10.5812/ kowsar.1735143X.797

Copyright $\odot 2012$ Kowsar M. P. Co. All rights reserved.

acquiring one or more parenterally transmitted infection, such as HIV, HCV, HBV and HTLV-1 (7).

In Iran opiates are the most commonly abused drug type, and it has been estimated that $2.8 \%$ of adults ages 15 to 64 are opiate abusers $(8,9)$. Also, data from the 2006 Spengler Forum Index revealed that $12.2 \%(180,000)$ of drug abusers were injecting drug users (IDUs; [10]). Another study that year with a different dataset estimated that there were 200 to 300 thousand IDUs with a mean age of $33 \pm 8.9$ years in Iran (11). Nearly $40 \%$ of Iranian prisoners were IDUs, and the prevalence of HCV infection among this population has been reported to be between 38 and $90 \%(12,13)$. HCV seroprevalence among prison inmates varies markedly from country to country, but as a whole, research has shown that drug-abusing prisoners and habitual injectors were 90 times more likely than healthy blood donors and the general population to be infected with HCV (14-16). The risk of testing positive for HCV among prisoners was found to be associated with marital status, duration of drug use, IV drug use, shared injection equipment, duration of incarceration, tattoos, and number of times in prison (13). The point prevalence of sterile-syringe use was $85 \%$ among IDUs, but a history of sharing injection equipment was reported between 50 and $70 \%$ of them $(9,17)$. Another study has shown that tattoos might have a higher risk of HCV infection when given in prison (18). Mirahmadizadeh et al. found that 
the proportions of unsafe and unprotected homo- and heterosexual contact among IDUs were $19.4 \%$ and $37.4 \%$, respectively (19).

Today, injecting drug abuse is a major and perhaps the most important risk factor for HCV infection (20). Intravenous drug abusers not only have the highest prevalence of HCV infection but also constitute a potential reservoir of HCV in the community (6). Injecting drug use and health care provision are the most important risk factors for $\mathrm{HCV}$ infection, and the number of HCVinfected persons continues to grow (21). In early reports from Tehran in 2001 by Zali et al., ELISA tests were HCV Ab positive for $45 \%$ of imprisoned IDUs (22). About $38 \%$ of IDU prisoners in the western province of Hamadan, 47\% in the northwestern province of Zanjan, 52\% in Tehran, $64.8 \%$ in the southern cities of Bandar Abbas and Roodan, and $88.9 \%$ in the northern of Guilan were HCV Ab positive, whereas the rate in non-IDUs in prison was much lower $(1,13,23,24)$. Iran has one of the highest per capita numbers of opioid users in the world, with a substantial and potentially growing proportion of IDUs $(8,9)$. The dramatic growth in the number of prisoners involved in high-risk behaviors and the high rates of community reentry emphasize the need for screening, detection, and treatment of HCV infection as well as harm-reduction programs to help curtail the rise of HCV infection in incarcerated populations and the general population (1). Because many drug users spend time in prison, it is an appropriate to break the cycle of infection by multidisciplinary interventional approaches targeted at controlling the further spread of these infections among prisoners and to the general population. Intervention efforts have expanded progressively to include comprehensive HIV prevention with epidemiological surveillance, educational programs, research activities, and methadonemaintenance therapy, but they must further incorporate components such as HCV-specific educational programs and encourage inmates to avoid tattooing while in prison $(25)$.

\section{Authors' Contribution}

None declared.

\section{Financial Disclosure}

None declared.

\section{References}

1. Brown RS, Jr., Gaglio PJ. Scope of worldwide hepatitis C problem. Liver Transpl. 2003;9(11):S10-3.

2. Jacobson IM, Davis GL, El-Serag H, Negro F, Trepo C. Prevalence and challenges of liver diseases in patients with chronic hepatitis C virus infection. Clin Gastroenterol Hepatol. 2010;8(11):924-33; quiz e117.

3. World Health Organization. Immunization, Vaccines and Biologicals. Hepatitis. WHO; 2011 [updated 2011 March 23]; Available from: http://www.who.int/immunization/topics/hepatitis/en/ index.html.

4. Burattini M, Massad E, Rozman M, Azevedo R, Carvalho H. Correlation between HIV and HCV in Brazilian prisoners: evidence for parenteral transmission inside prison. Rev Saude Publica.
2000;34(5):431-6.

5. Weild AR, Gill ON, Bennett D, Livingstone SJ, Parry JV, Curran L. Prevalence of HIV, hepatitis B, and hepatitis $C$ antibodies in prisoners in England and Wales: a national survey. Commun Dis Public Health. 2000;3(2):121-6.

6. Alavian SM, Adibi P, Zali MR. Hepatitis C virus in Iran: epidemiology of an emerging infection. Arch Iranian Med. 2005;8(2):84-90.

7. Zeldis JB, Jain S, Kuramoto IK, Richards C, Sazama K, Samuels S, et al. Seroepidemiology of viral infections among intravenous drug users in northern California. West J Med.1992;156(1):30-5.

8. Mokri A, Taherinakhost HR, Chawarski MC, Schottenfeld RS. Opium dependence in Iran: A continuing habit with intriguing nature and course. Poster session presented at the 67th Annual Scientific Meeting of the College on Problems of Drug Dependence; 2005 June 18-25; Orlando, Florida. 2005.

9. United Nations Office on Drugs and Crime. World Drug Report. Vienna: UNODC; 2005.

10. Spengler Forum Index. Epidemiology of drug use in Iran 2006 [updated 2006 Dec 23]; Available from: http://spengler.atimes. net/viewtopic.php? $\mathrm{p}=194050 \&$ sid=839119d0cb51a723c9c2b6af6 9eaa025.

11. Razzaghi EM, Movaghar AR, Green TC, Khoshnood K. Profiles of risk: a qualitative study of injecting drug users in Tehran, Iran. Harm Reduct J. 2006;3:12.

12. Mohammad-Alizadeh AH, Alavian SM, Jafari K, Yazdi N. Prevalence of HBsAg, HCV Ab, and HIVAb in drug abuser prisoners in Central Hamadan Jail. J Res Med Sci. 2002;7:311-3.

13. Mohtasham Amiri Z, Rezvani M, Jafari Shakib R, Jafari Shakib A. Prevalence of hepatitis $C$ virus infection and risk factors of drug using prisoners in Guilan province. East Mediterr Health J. 2007;13(2):250-6.

14. Alavian SM, Gholami B, Masarrat S. Hepatitis C risk factors in Iranian volunteer blood donors: a case-control study. J Gastroenterol Hepatol. 2002;17(10):1092-7.

15. Gates JA, Post JJ, Kaldor JM, Pan Y, Haber PS, Lloyd AR, et al. Risk factors for hepatitis $\mathrm{C}$ infection and perception of antibody status among male prison inmates in the Hepatitis $C$ Incidence and Transmission in Prisons Study cohort, Australia.J Urban Health. 2004;81(3):448-52.

16. Skipper C, Guy JM, Parkes J, Roderick P, Rosenberg WM. Evaluation of a prison outreach clinic for the diagnosis and prevention of hepatitis C: implications for the national strategy. Gut. 2003;52(10):1500-4.

17. Celentano D, Beyrer C. Public Health Aspects of HIV/AIDS in Low and Middle Income Countries: Epidemiology, Prevention and Care. JAMA. 2009;302(5):574-5.

18. Zamani S, Ichikawa S, Nassirimanesh B, Vazirian M, Ichikawa K, Gouya MM, et al. Prevalence and correlates of hepatitis $\mathrm{C}$ virus infection among injecting drug users in Tehran. Int J Drug Policy. 2007;18(5):359-63.

19. Mirahmadizadeh AR, Majdzadeh R, Mohammad K, Forouzanfar MH. Prevalence of HIV and Hepatitis C Virus Infections and Related Behavioral Determinants among Injecting Drug Users of Drop-in Centers in Iran. Iran Red Crescent Med J. 2009;11(3):325-9.

20. Alavian SM, Fallahian F. Epidemiology of Hepatitis $C$ in Iran and the World. Shiraz E Med J. 2009;10(4):162-72.

21. Baveja UK, Chattopadhya D, Khera R, Joshi PM. A cross sectional serological study of the co-infection of hepatitis B virus, hepatitis $C$ virus and human immunodeficiency virus amongst a cohort of IDUs at Delhi. Indian J Med Microbiol. 2003;21(4):280-3.

22. Zali MR, Aghazadeh R, Nowroozi A, Amir-Rasouly H. Anti-HCV antibody among Iranian IV drug users: is it a serious problem. Arch Iran Med. 2001;4(3):115-9.

23. Davoodian P, Dadvand H, Mahoori K, Amoozandeh A, Salavati A Prevalence of selected sexually and blood-borne infections in Injecting drug abuser inmates of bandar abbas and roodan correction facilities, Iran, 2002. Braz J Infect Dis. 2009;13(5):356-8.

24. Khani M, Vakili MM. Prevalence and risk factors of HIV, hepatitis $B$ virus and hepatitis $C$ virus infections in drug addicts among Zanjan prisoners. Arch Iranian Med. 2003;6(1):1-4.

25. Health and Treatment Headquarter. [An overview on HIV/AIDS in prisons of Islamic Republic of Iran]. Tehran: Iran Prison Organization; 2006; Available from: http://www.ncbi.nlm.nih.gov/pmc| articles/PMC2900562/. 